\title{
Rape as a weapon in genocide and wars: Enquiring the problems of women's witnessing rape
}

\author{
Yuyun Sri Wahyuni \\ Global Gender and Sexuality Studies \\ State University of New York at Buffalo, New York, United State \\ Email: yuyunsri@buffalo.edu
}

\begin{abstract}
This paper seeks to better understand rape as a weapon in genocide and wars, the myriads contributing factors to creating ignorance to rape as a weapon in genocide, other forms of sexual violations, and circumstances that prevent women from witnessing rape acts of genocide violence. Drawing from the feminist perspectives of rape and women's sexual violence theorization, Derrida's accounts of truth and witness, and women as an improper mythic being-tainted witness, this paper shows that the current global gender inequality discrimination perpetuates the practice of rape as a weapon of genocide and wars as well as a repudiation for women's witnessing rape and sexual violations. As this situation of women rape survivors' desertions are not only happened in the Rwanda genocide and witnessing rapes for rape victims and survivors are equally challenging, this paper serves an alternative to support women's witnessing rapes and prevent rape the weapon of war to reoccur in the future. Further, Derrida's considerations on law should extend the notions of witnessing beyond the traditional European juridical tradition that excludes literature from legal exercise of witnessing as literature is regarded as mostly only fiction upbrings witnessing through literature as secret testimony is a useful interpretation on women's witnessing rape. Deciphering Derrida's description
\end{abstract}


of witnessing through literature, this paper also recommends that women's writing literature can be an effective way for women to testify independently of the various gendered political disciplining gazes that hold them back from giving testimonies and then gain liberations.

Keywords: Rape as a Weapon, Sexual Violation Against Women, Derrida's Secret Testimony, Women as Witness.

\section{Introduction}

In the history of the world genocide, women and girls are regarded as the most disadvantaged. Partly, it is because women are deemed weak that they cannot protect themselves from violence. Further, they are also often targeted as objects of power in genocides because of the mythic thinking upon their ontology and bodily subjects (Beauvoir, 2012), their reproductive duties, and their gender positions that are out of balance with men, especially in the eyes of men who commit rape for genocide acts.

Forms of injustices towards women and girls during the genocide include repeated individual rapes, gang rapes, tortures, inserting weapons and other subjects into victim's organ, murders after sexually violated, mutilations, and rape the killing (MacKinnon,1994; Kirby, 2012). In wars and genocide settings, women's and girls' rapes, tortures, and murders are used as instruments to humiliate and destroy the whole genocidal-targeted families and communities.

Different records of genocides from the Holocaust to Myanmar show significant fatalities of women and girls who were raped, tortured, or murdered. However, despite such fatalities, there have not been balanced responses to giving justice and healing to women as victims during genocides. In Rwandan genocides, the highest numbers of victims are women and girls who were raped, sexually tortured, and then killed (Eftekhari, 2004). If they escape murders and survive after being raped, the rape-survivors genocide lives are intensely tragic due to the loss of their families, friends, and almost everyone they knew and because of their experience of the deepest traumas that could never be forgotten, including the presence of children born as a result of rape during the genocide seasons. Among the common situations that the genocide survivors share are their strange temporalities, their brokenness, and their no life in life conditions. In women rape-genocide survivors, such shared characteristics are worse as women are also subjected to different social stigmas and hardship after experiencing the rape. 
Despite the suffers that women rape-genocide survivors are great and the continuation of using rape as a war and genocide weapon, the response towards rape crimes during the Rwandan genocide and in another world darkest humanities investigations, however, remained insignificance. In the case of the Rwandan rape genocide, Eftekhari (2004) suggests that the lack of rape justice assessment is due to the deficiency of women and gender just perspectives trained personnel within the investigators, judges, and courts. Worse of all, in different settings of rape occurrence, women were considered as those who do not have access to proper witnessing as well as the power of resisting the gender-based witness smothering (Dotson, 2011; Alcoff, 2018), if women witness, their witnesses are considered tainted (Gilmore, 2016). In the shed light of this situation, this paper attempts to further understand the topic of women's rape as a weapon of genocide and different factors that contribute to creating ignorance to rape weapon in genocide. Additionally, this paper also clarifies various situations that hinder women from witnessing rape as acts of genocide violence.

Framing through the feminist perspectives of rape and women's sexual violence, Derrida's account of truth and witness, and women as improper mythic being-tainted witnesses, this paper argues that global gender inequality ignorance helps maintain the practice of rape as a weapon of genocide. As this situation of women rape survivors' desertions are not only happened in the Rwandan genocide and witnessing rapes for rape victims, and survivors are equally problematic, this paper may serve as an alternative to support women's witnessing rapes and prevent rape as the weapon of war to reoccur in the future.

\section{Literature Review}

\section{Rape as Weapon in Genocide and War}

Genocide, as it is defined in the United Nation's convention of 1948, is various acts committed with intentions to destroy the whole, or in part, a national, ethnical, racial, or religious group, through different acts of violence such as assassination the members of the group, instigating grave physical or psychological harm to members of the group, intentionally perpetrating on the group conditions of life designed to bring about its corporeal destruction in whole or in part, imposing procedures intended to thwart births within the group, forcibly removing children of the group to another group (UN-Refuse Facism, 2018). 
Despite this clear definition provided by the UN, understanding the occurrence of genocide is never an easy matter. The sense of superiority over the others, uncontrolled anger, deep-rooted politicized hatred, and the lust to the power of domination and diminishing others stand before various forms of human crimes committed during genocides that go beyond the capability of human's sense of reasoning. In Rwandan genocide, where half a million to million victims were killed using machete-traditional methods of killing by militias and ordinary peasants to their long known and live together with neighbors, different accounts of narrations attempt to explain the occurrence. Still, scholars regard that each given explanation does not represent the conundrum's deep layers in such massive brutal killings and tortures. In Life Laid Bare, for example, accounting different life narrations of the survivors after the genocide, Hatzfel (2007) contends that we would never be able to understand the whole spectrum of the Rwandan genocide, especially in the perspective of the victims, yet, we can only approach it, as close as we can. Hatzfel further suggests that we could never know the heart of genocide as the survivors themselves never know about such secret encrypted knowledge of the genocide that they never have access to it. Narrated, in his book, "the truth about me is that I do not know the truth about me. I know there is something about myself that I do not know how to get to it."

However, despite this difficulty of understanding the occurrence of genocide comprehensively, several analyses (Newburry, 1998; Des Forges, 2008) record that there is at least one agreed on understanding towards genocide: from the Rwandan genocide, genocide was long prepared in different historical political and genocide-ideological stages. In the Rwandan context, the sense of segregation, hatred, and ideologies of extreme otherness of the others formed during the colonial era of political identities and continuedly fertilized in different political agenda settings, sedimented in various arrangements of embodied communal segregations and post-colonial ethnic separations, and thus, become the apt habitus for the widely spread ideology of genocide.

During the genocide, women's and some men's bodies are targeted for rape. In Rape, Genocide, and Women's Human Rights, MacKinnon (1994) criticizes the human rights universalities concept that neglect realities of women's different needs than men's needs. She narrates that women are human as men also human; they bleed if they are cut as men also suffer when they are cut. Women are also despoiled in numerous ways, as men are in many ways. However, women violated differently in ways that men are violated, especially in sexually 
and reproductively related violations. In Serbia's Bosnia and Herzegovina invasions' massive rapes, the legal report shows that women are sexually and reproductively violated as part of strategic war policies of genocide. MacKinnon strengthens her argumentation in logical order rhetoric: rapes are tools of the war as wars are the genocide instruments. She contends further that genocide does not come from empty vacuum realities, as rapes also do not. Rapes in war and genocide embody different ideologies of hatred, patriarchy, and oppressive bloody domination that are also used to fuel genocide. Rapes, in this sense, as MacKinnon strongly condemns, are used as structural policies within genocide's tactics and performed as a daily practice of diminishing people:

In this genocide through war, mass rape is a tool, a tactic, a policy, a plan, a strategy, and a practice. Muslim and Croatian women and girls are raped, then often killed, by Serbian military men, regulars, and irregulars in a variety of formations, in their homes, on hillsides, in camps-camps that used to be factories, schools, farms, mines, sports arenas, post offices, restaurants, hotels, or houses of prostitution. The camps can be outdoor enclosures of barbed wire or buildings where people are held, beaten, and killed and where women, and sometimes men, are raped. Sometimes the women are also raped after they are killed. Some of these camps are rape/death camps exclusively for women, organized like the brothels of what is called peacetime, sometimes in locations that were brothels before the war. ... rape directed toward women because they are Muslim or Croatian...

After world war I and II, different agreements were signed to avoid targeting the civilians, until recently, however, there has been reappearance on combating the non-combatants, including the use of rape and other means of sexual violence as a weapon on wars (Sitkin, X. Lee \& Lee, 2019). In 2008, the United Nations enacted the Security Council 1820, which covers the recognition of rape as a weapon and war tactic. This 1820 resolution asserts that rape and various sexual violence methods are war crime and crimes against humanity, equals genocide crime. Other than equalizing rape as a weapon of war to genocide crime, the 1820 resolution also calls for more women deployments in peace operations and troop training on preventing and responding to sexual violence:

Noting that civilians account for the vast majority of those adversely affected by armed conflict; that women and girls are particularly targeted by the use of sexual violence, including as a tactic of war to humiliate, 
dominate, instill fear in, disperse and forcibly relocate civilian members of a community or ethnic group; and that sexual violence perpetrated in this manner may in some instances persist after the cessation of hostilities; Recalling its condemnation in the strongest terms of all sexual and other forms of violence committed against civilians in armed conflict, in particular women and children;

Reiterating deep concern that, despite its repeated condemnation of violence against women and children in situations of armed conflict, including sexual violence in situations of armed conflict, and despite its calls addressed to all parties to armed conflict for the cessation of such acts with immediate effect, such acts continue to occur, and in some situations have become systematic and widespread, reaching appalling levels of brutality...

Referring to this resolution, different academic researches, political advocacies, and media reports on wartime sexual violence, Kirby (2012) regards rape widely recognized today as a systematic tactic of war, a war crime, and fundamental acts of genocide. Nevertheless, Kirby suggests that the positive responses and good political will from different institutional elements in other countries on rape as a weapon is still minimal on action levels despite the enormous physical and psychological damages on women and girls caused by rape as a weapon of war. Different wars and acts genocides in other parts of the world today indicate that rape as a weapon is still largely used as tactics in many additional human rights bothering wars and genocides. Women and girls in Myanmar, Columbia, Iraq-ISIS wars, and more places in armed conflicts are currently sexually violated.

\section{Results and Discussion}

\section{Global Gender Injustices as the Main Origin of Rape as Weapon Persistence}

Assessing the world's impunity on rape as a weapon of a war crime, Hillen (2016) narrates that the country's broader international socio-political-economic interests often prevent them from giving adequate responses to tackle the problem of rape as a weapon in wars/genocide. Further, on explaining women rapes as a weapon in war conditions in Congo's massive rape on women, Hillen argues that if we have not solved gender inequality problems within our world society, we will, unfortunately, see rape as a weapon reoccur. Contextualizing from Congo's massive Rape, Hillen explains that it is only women responsible 
for food-water gathering in Congo while men usually stay sit on the porches of their house. It is during this time of resource gathering that women are sexually targeted.

If only the socio-gender construct changes- men and women work together in their domestic-public spheres, rapes on women could not be so massive in Congo. If only our gender constructs do not marginalize women from justice and humanity, we will not see a different reoccurrence of rape as a weapon of wars, justice is given to survivors, and our world majority will not remain silent about it. Rape is intended to humiliate, terror, and dismiss the whole community members targeted in genocide concerning gender inequality constructs.

Card (1996) argues that rape both in peaceful time and wartime as weapons embodies one fundamental function: to show, communicate, create, or preserve dominance. Rape is a common-universal language of domination. It could be domination by or of males. In our social construct, where women are under men's protections, rape has social meaning. Women in our different traditional-modern social accounts exchange services with men for protections. In these gendered social bonds of men and women, rape is intended to send messages to the community's men and to the whole community, ethnic, race, nation, that the women under their protections are threatened, and they fail to protect. Another way of saying, raping women, the perpetrators urge their victims to seek protections while they are being tortured. Card (1996) further explains that there is not only one way to commit genocide, besides massmurdering, slaughtering, enslaving, and destroying such social ties in families, communities, or nations, then showing tortures before dismissing the whole members of genocide targeted entirely is also among tactics of genocide. All these genocide crimes that our humanity bothered are repeatedly utilized to create or maintain domination over peoples, resources, and powers.

In The Greatest Silence, Rape in Congo (Jackson, 2007), it is powerfully narrated how Rape in Congo represents explanations of how rape as a war weapon is a form of severe gender inequality and silencing women from speaking about it. Paramilitary men feel that they can gain magical power potion after they rape; besides, they also rape because they feel the need women vent their power and their sexual desires, where after they raped, they felt more determined both as men and as soldiers.

In and after the Rwandan genocide, mass sexual violence attends genocide tactic strategic and political purposes. Based on both their gender 
and their ethnic affiliation, Tutsi women are ideologized as sexual transgressors for Hutu men to achieve Tutsi dominations over the Hutus. Based on such ideology of Tutsi women, Hutu genocide perpetrators massively rape Tutsi women and moderate Hutu women to put shame, instill Hutu's dominations over Tutsi, and to cleanse Tutsi ethnic from their lands. Before and after the genocide, however, the use of sexual violations is not strange to Rwandan Tutsi and Hutu's realities. Before the genocide, Hutu women were targeted by the Rwandan Patriotic Army (RPA) extremists. In contrast, after the genocide, Tutsis' survivors are forced married to RPAs members as a form of reciprocation after being saved during the genocide season (Twagiramariya \& Turshen in Eftekhari, 2004). Making women's bodies as objects political anger, community despairs and resentments, and power-seeking rebels in pre-during and postgenocide in Rwanda denotes various gender subordination layers, men and women inequalities.

\section{Women Witnessing Rape as Weapon in Wars/Genocide}

"Rape did not necessarily occur in public. How can one accept the testimony of the victim without there having been a witness? What will happen when the accused pleads not guilty?" WK Human Rights Interview in Gitarama, Rwanda. (Eftakhari, 2004)

In various wars and genocides, the number of female rape victims is vast. This vast number is inversely proportional to what we have after the wars and genocides from the data of victims who reported rapes happened to them. The United Nations data suggests that only a low percentage (one percent) of women raped in wars and genocide report the rapes when they survive. In massive rapes during the Rwandan genocide, Eftakhari (2004) records that from December 1996 to December 2003, the Rwandan Tribunal of First Instance and military court tried 9.728 persons for different genocide crimes against humanity. Of this thousand's numbers of court judgments, the Human Rights Watch examined over 1000 court filing and decisions and found that only 32 included rape and sexual torture cases. Prosecutors were mainly informed that the victims failed to report their rape and sexual violation cases before the laws so that the number of rape cases is minimum.

Women's reluctance to report rapes and other sexual violations before the court and give testimony on rape and other sexual violations is not something that only happens in the genocide and war situations. Under the 
normal peaceful condition, the $2015 \mathrm{UN}$ data release shows that within the large number of sexual assaults that women experience, one in three women experienced sexual violation in different nations worldwide. Only significantly small numbers of women reported the sexual assaults to the police. In most countries, less than $40 \%$ of women sought help, and less than $10 \%$ sought help from the police.

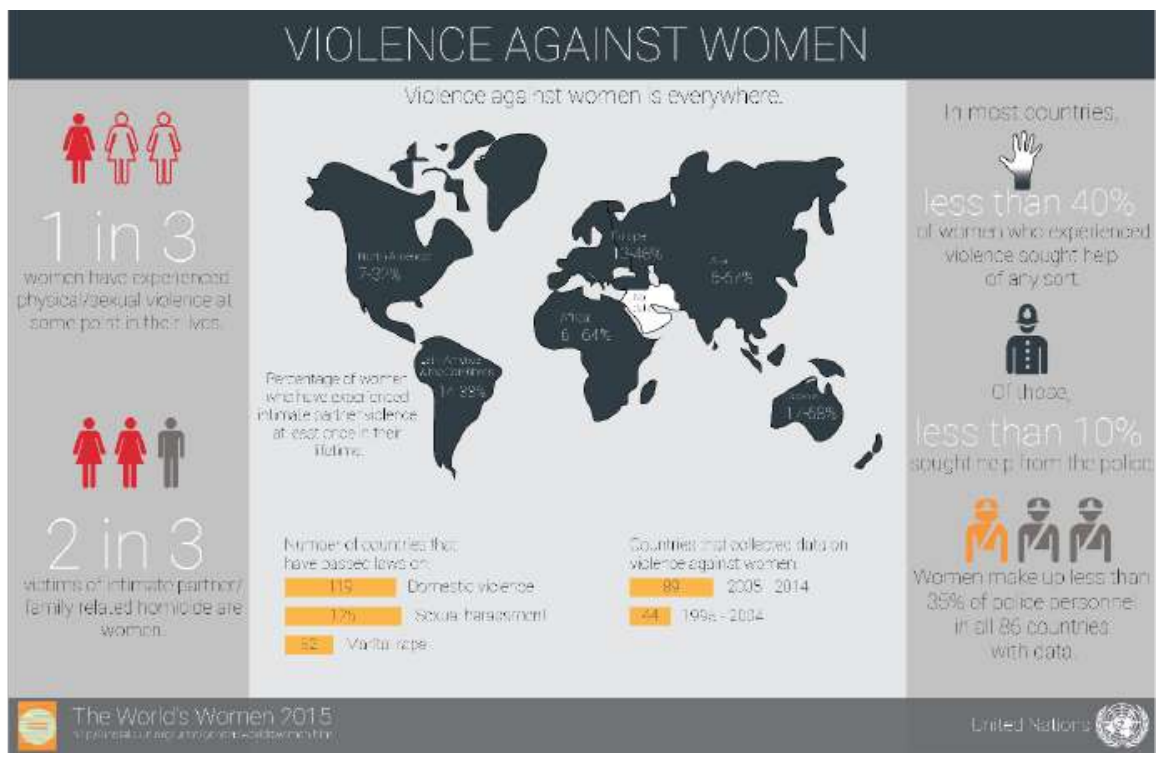

Different reasons explain why women are reluctant to report their sexual violations before the system worldwide from lack of adequate institutional governance and goodwill on eliminating gender-based violence, to different other socio-cultural religious barriers. In the context of the Rwandan genocide, rapes and sexual crimes as a weapon of genocide, almost all the reported factors that hinder women from reporting as giving witness in rape as a weapon of genocide and war represent similar problems that underlay women's reluctance of witnessing rape and sexual assaults before formal institutions in normal peaceful conditions, but much worse. Eftekhari (2004) shows that the conditions that hinder women from reporting including the lack of protection from the Rwandan justice system to women who reported rape and sexual crimes, the absence of victims' privacies and confidentialities, stigmatizations, and fewer considerations of rape and sexual crimes as serious humanity crimes in local genocide investigators due to Rwandan socio-cultural constructs of gender 
imbalances during the court times.

The lack of evidence that women can provide in the court for the alleged rapists is also significant for women not reporting rape during genocides. Rape victim's inability to identify the assailants, lack of physical evidence, or eyewitness testimonies are also among the reasons for women hindering report for the rape or other sexual crimes in Rwanda (Eftakhari, 2004). The questions of evidence, self-narration of her story, and his story problems (Alcoff, 2018) within feminist theoretical discussions of justice for rape victims are complex delicate situations as in different social patriarchal settings, very rarely her story is accounted. In benign condition, this is already problematic, in a genocide setting, this standpoint positionality to women is doubled in difficulties unless again if there is goodwill in the patriarchal system to reform and set alignment to women and victims. In Tainted Witness Why We Doubt Women Say About Their Lives, Gilmore (2016) considers that women's testimonies demonstrate both women's bodies and speech in the public sphere and the lack of institutional security where women can safely claim their bodies. The absence of this institutional security shared in various justice institutional settings hinders women from getting justice.

If women did report, however, another question of distrusts was raised. From the data in the Human Rights report of Rwanda (Eftakhari, 2004), most of the narrations provided by the women victim show that they live only with tiny relatives left because most of their families were murdered, while the perpetrators are along with their bands of family supports. These women feel that they are most likely to be distrusted if they report and proceed with their justice claims. Different sets of societal contexts of stigmatization, doubts, and shame towards women victims of rape and sexual violations have also become the problems that must be dealt with after women file their reports (Eftakhari, 2004). In most of our gendered society setting, and that of clearly in Rwandan social construct, women are blamed for their being victims of rape and sexual crimes. Women are blamed for the ways they dress, how they speak, the ways they walk, or just in the ways they are women. Gilmore (2016) argues that through additional evidence and analysis provided in her book, it is essential to bring feminist perspectives on women's bearing witness, as women's witness is subjected to humiliations and dishonor through shame in different ways to contaminate women's witness with doubts and then dismiss their witness.

In Rape and Resistance Understanding the Complexities of Sexual Violations (Alcoff, 2018) brings the significances of providing discourse that allow 
women's liberation from oppressive traumatic experiences through witnessing. Framing her Speaking As with Laura Gray-Rosendale chapter through Foucauldian realms of discourse, Alcoff concerns that failure to provide secure discourses for women's witnessing rape, and compulsion to ensure whichever details of women's experiences and inner life as well as inadequacies to maintain a nondisciplining gendered gaze that reflects gendered power exercises bring different counterproductive political consequences to women's witnessing rapes:

Foucault worried that subjects who were compelled to speak about their experiences and inner life with whichever detail could become subjected to a disciplining gaze, which adverse political consequences. The confession, he argues, "unfolds within power relationship, for one does not confess without the presence (or virtual presence) of a partner who is not simply an interlocutor but the agency that requires confession, prescribes it, and appreciates it, and intervenes to judge, punish, console, and reconcile" (Foucault in Alcoff, ).

In the Problem of Speaking for Myself, Alcoff (2018) regards that often philosophers consider the self-narrativizing piece as problematic. However, Alcoff argues that the self-narrativizing allows us to reach possibilities of different productive epistemic assessment about the first-person absolute claim's points of view. Alcoff provides an example of powerful self-narration Merleau-Ponty provided regarding his deeply personal experiences, self-critical transformations of sensibilities, and reflective awareness about social structure conditions after the world war II ends. Alcoff contends that Merleau-Ponty's narratives stand for one method to form general empathy and even moral agencies' broad claims. She further mentions that if Merleau-Ponty's work is not narrated in the first person-narrative accounts, his work would not contain rich resources of understanding the delicate orders of oppressive social relations that "can be sedimented into our habitual embodiment, imaginary, and perceptual practices." In her supports on the use of personal narrative as a means of selfwitnessing, Alcoff suggests that personal narrative of witnessing is not a domain of single perspective truth absoluteness. It is, instead, a site for both discoveries and critiques. Using a productive approach to solve the problem of women's testimony in rape, such as that offered by Alcoff, women can have a space of narrating their experiences without concerns about disciplining gendered gaze problems. 


\section{Women's Witness Silencing and Its Liberation}

Truth, as we examined in the world of praxis, is the consensus of power and ideologies. Those who are in power may define truth in accord with their need for truth definition. Within our philosophical academic and practice layers and the world political inquiries, we often examine the description of how truth is a consensus of power and ideologies, and the ability to convey truth is in the hands of those in power. Among the agreed expectations of the powerful is the oppressed supposed not to speak about the truth. In this way, there have been different instrumentalizations of silencing practices upon the oppressed, such as creating different social taboos and sets of conduct of what can be delivered and what is not. The examples of such prohibition and games of conduct vary, to mention one, social stigmatization, shaming, and blaming women as rape victims. In Congo, women do not tell their physical and inner experiences of rape even to their husbands and relatives as she will be subjected to rejections. Another way of silencing is intimidating and traumatizing, in which both ways, women must learn how to behave as expected as victims and suppress their traumatic conditions for themselves.

Using Spivak's Can the Subalterns Speak?'s epistemic violence terminology, Dotson (2011) underlies how the colonial tactic of the subaltern's knowledge elimination and replacing it by privileging alternative discourse of the Western colonial epistemologies is useful to understand how the practice of silencing women from testifying Rape and sexual crimes is prolonged. In the status quo of gender inequality construct, it is men's privileged knowledge, and it is also men's realms that are regarded as precedence. Women's live conditions that Bevoair (2012) describes in her Second Sex as living in the men's world through the realities of men see through the sights of men, and dream in the dreams of men are the conditions that are widely agreed upon today's gendered inequality world. Through such situations, it is understandable how women cannot possess their knowledge, and thus, it also becomes more apparent how women refuse to witness and how women's witnessing, if they bear witness, is often neglected. While in the case of the Rwandan genocide, women survivors' muteness to witnessing shows us how they see the non-belongingness towards knowledge of genocide and rape, as the knowledge of genocide lays in two hands, one in the hands of those who were murdered and the other is in the palm of the perpetrators who are most likely corrupt the knowledge of genocide. Knowledge of Rape lies in the hands of patriarchal histories of their socio-gender constructs.

In analyzing Blanchot's The Instant of My Death, Derrida's Demeure 
suggests how literature may serve both knowledge liberation from colonizing powers and testimonies before histories of dominations, oppressions, and genocides. Through his philosophical construct of historical witnessing and his deconstruction of literature as only fiction and poetry, Derrida goes beyond the limit of traditional European understanding of literature. In discussing Michael Lissse's Passions of Literature as the entrance to colonizing literature deconstruction, Derrida explains that there is already a significant disturbance in reading the title related to the number's law. Passions (plural) and literature (singular):

"This is not simply for fun, also, if this is a game, this is a serious game: the many passions devoted to literature, as one will of the passions that literature, literature itself, literature in general, can endure, suffer, accept or refuse. Literature would thus the subject as well as the object of these passions, as well as the canvas or in any case, the place passive and punishable, to which events supervene: an entire history awaits us."

It is also mentioned in Demeure that to understand European literature, one should realize European history. In Derrida's explanation, this imposed understanding of Europe's narrative brings an awakening of the singularity and the Latinity of literature as a word. As a word, literature conceives the imposing power on other differences being. Derrida says the consequences of this imposing power are infinite, universalizing the singularity, there is no question of even beginning to lay others out there. There must be a reciprocal activity of understanding the history and existence of other literature to liberate literature from its universalizing definition. Interpreting Derrida's universalizing singularity into women's witnessing rape realities, there is one universalizing history: men's history and deliberate rape assessment from singlesided knowledge construction, women's subjective histories should be counted equally.

\section{Conclusion}

Derrida considers that law should extend the notions of witnessing beyond the traditional European juridical tradition that excludes literature from legal exercise as literature regarded as especially only fiction. In this sense, Derrida also considers that secret testimony within historical literature equals public testimony as through literature-secret testimonies. Testifiers render their deepest secret to the public even though it is delivered in covert ways. At the 
same time, the author of such literature, as well as the narrator of the narration provided in literature present themselves as a witness to testify, even it is not (as Derrida puts it) in broad daylight witnessing. Women's writing literature, as we understand it from Derrida's description of witnessing through literature can be an effective way for women to testify independently of the various gendered political disciplining gazes that hold them back from giving testimonies and then gain liberations.

\section{References}

Alcoff, L. M. (2018). Rape and resistance. John Wiley \& Sons.

Bijleveld,C.,Morssinkhof,A., \&Smeulers,A.(2009).Countingthecountless: Rape victimization during the Rwandan genocide. International Criminal Justice Review, 19(2), 208-224. https://doi.org/10.1177/1057567709335391.

Card, C. (1996). Rape as a Weapon of War. Hypatia, 11(4), 5-18. https://doi. org/10.1111/j.1527-2001.1996.tb01031.x.

De Beauvoir, S. (2012). The second sex. Vintage.

Derrida, J. (2000). Demeure: Fiction and testimony. Stanford University Press

Dotson, K. (2011). Tracking epistemic violence, tracking practices of silencing. Hypatia, 26(2), 236-257. https://doi.org/10.1111/j.15272001.2011.01177.x.

Eftekhari, S. (2004). Rwanda, struggling to survive: Barriers to justice for rape victims in Rwanda (Vol. 10). Human Rights Watch.

Forges, A. D. (1995). The ideology of genocide. Issue: A Journal of Opinion, 23(2), 44-47.https://doi.org/10.2307/1166506

Gilmore, L. (2017). Tainted witness: Why we doubt what women say about their lives. Columbia University Press.

Hatzfeld, J. (2013). Life laid bare: The survivors in Rwanda speak. Other Press, LLC.

Hillen (2016). Rape as a weapon of war: The untold story of Armed Conlict. Retrieved from Aljazeera English at https://www.youtube.com/ watch?v=p8gtEmB9u9I

Jackson, L. F. (2007). The greatest silence: Rape in the Congo. New York, NY: Women Make Movies.

Kirby, P. (2013). How is rape a weapon of war? Feminist International 
Rape as a weapon in genocide and wars: Enquiring the problems of women's witnessing rape (Yuyun Sri Wahyuni)

Relations, modes of critical explanation and the study of wartime sexual violence. European Journal of International Relations, 19(4), 797-821. https://doi.org/10.1177/1354066111427614.

MacKinnon, C. A. (1994). Rape, genocide, and women's human rights. Harvard Women's

Newbury, C. (1998). Ethnicity and the politics of history in Rwanda. Africa Today, 45(1), 7-24.

Ruby Reid-Cunningham, A. (2008). Rape as a weapon of genocide. Genocide studies and prevention, 3(3), 279-296.

Sitkin, R. A., Lee, B. X., \& Lee, G. (2019). To destroy a people: Sexual violence as a form of genocide in the conflicts of Bosnia, Rwanda, and Chile. Aggression and violent behavior, 46, 219-224. https://doi. org/10.1016/j.avb.2019.01.013.

What is genocide (According to the UN and International Law). (2018). Retrieved from https://refusefascism.org/2018/01/29/what-is-genocideaccording-to-the-un-and-international-law/

Violence against women chapter 6. (2015). Retrieved from https://unstats. un.org/unsd/gender/chapter6/chapter6.html 
Journal of Social Studies (JSS), Volume 16, Number 2, 2020: 121-136 